\title{
Synthetic and Analytic Present and Past Verb Forms in English, German and Czech
}

\author{
Dagmar Masár Machová*, Petra Charvátová**, Petra Bačuvč́ḱková***
}

\begin{abstract}
The paper compares three languages - English, German, and Czech in terms of the verbal subcategories that denote present and past states and actions. It shows that all three languages use precisely two tenses - present and preterite, and they can be expressed either synthetically (English, German) or analytically (Czech). Furthermore, the paper studies the issue of grammatical aspect, comparing English, which has perfect and progressive aspect, with German, which has perfect aspect, and Czech, which also expresses perfect aspect grammatically - this is frequently labelled as Slavic perfect. This structure in Czech is, however, not regarded as a purely grammaticalized category of aspect by many scholars, such as Karlík and Migdalski (2017).
\end{abstract}

Key words: tense, aspect, perfect, preterite, preterite perfect

Tomas Bata University in Zlín, Czech Republic

** Palacký University Olomouc, Czech Republic

**** Tomas Bata University in Zlín, Czech Republic 


\section{Objective of Study}

This paper focuses on English, German and Czech, and analyzes the verb forms that each language uses to denote present and past states and actions. The goal is to determine to what extent the three languages differ in their verbal morphosyntactic inventory. In order to compare the languages, the paper analyses the verb forms in terms of verbal subcategories (more precisely tense and aspect), and studies whether they are realized synthetically or analytically. We also briefly discuss the semantics of the verb forms, i.e. the meanings that particular verb structures convey. The study is mainly synchronic, reflecting the present-day grammatical structures, but in a few cases, the developmental tendencies are mentioned.

\section{Morphological Typology of the Languages in Question $^{1}$}

In terms of the number of morphemes per word, Comrie (1989) recognizes isolating/analytic and (poly)synthetic languages. Analytic languages (such as Vietnamese or Chinese) do not have bound morphology, i.e. one word corresponds to one morpheme - see example (1). On the other hand, synthetic languages combine a number of morphemes into a single word, as in Czech - example (2).
(1) Wo zhu zai Bulage.
I live in Prague
"I live in Prague."
(2) $\check{Z} i j-u \quad v \quad$ Praz-e. $\quad$ Czech
live-1.SG ${ }^{2}$ in Prague.LOC.SG
"I live in Prague."

Whereas in (1), one word contains exactly one morpheme, the Czech example (2) demonstrates that a single word, typically a noun, adjective, or verb consists of more than one morpheme.

Another perspective of classification refers to the degree of fusion. In agglutinative languages (such as Turkish, for example), one morpheme strictly corresponds to one subcategory. This means that the boundaries between the morphemes are clear-cut see (3). On the other hand, fusional languages (for example Russian, Czech) have mor-

\footnotetext{
1 The paper uses terminology based on the typological division of languages formulated by Sapir (1921) and further developed by Comrie (1989, 42ff.).

2 Glosses are explained in the appendix.
} 
phemes that "fuse" several morpholosyntactic features, i.e. there is a correpondence of one morpheme to several features correspondence - see (4).

(3) adam- lar- in Turkish

man PL GEN

"man's"

(4) stol- $\stackrel{\circ}{u}$

Czech

table GEN.PL

"of tables"

In example (3), each hyphenated morpheme carries one grammatical feature (namely number and case). On the other hand, the example from Czech (4) demonstrates that a single morpheme carries both number and case features.

Natural languages are not perfect representatives of the morphological typologies, i.e. no language is completely isolating or agglutinative (see for instance Sapir (1921) or Skalička (1966)). Therefore, the typology is traditionally represented by two scales indicating the degree of synthesis and fusion in a language (Sapir 1921), as presented in Figure 1 below.

$$
\begin{array}{llll}
\text { Index of synthesis: } & \text { analytic } & \longleftrightarrow & \text { synthetic } \\
\text { Index of fusion: } & \text { agglutinative } & \text { fusional }
\end{array}
$$

Figure 1: Morphological Typology

The two indexes represent relative scales, not absolute ones, and they work well for a comparison of languages. More interestingly, a single language can realize different grammatical phenomena variably with respect to the morphological typology. That is, in English the subcategory of number is productively expressed using a bound morpheme $-s$, but determination is expressed analytically, i.e. by a free morpheme the or a. The following section attempts to state the morphological tendencies observed in the three languages, especially from the perspective of the index of synthesis - more precisely, it poses the question whether the languages are more analytic or synthetic.

\subsection{English}

Referring to the typology presented above, English is frequently described as an analytic, rather than synthetic language, with respect to the degree of synthesis. This can be illustrated by modality or aspect features, see (5). The modal and aspect are realized by free morphemes, not by bound morphology on the lexical verb.

(5) He must have been examined. 
However, it is by far not an extreme example of an analytic language (such as Chinese), since it does possess a (relatively limited) inventory of bound morphemes, such as the plural $-s$ or 3rd person singular present morpheme -s. Bound morphemes can be both of a fusional and an agglutinative type. Agglutination can be found in word-formation, i.e. with derivational morphology, see (6) where every morpheme derives a different part of speech.

(6) depart- ment- al

noun adjective

On the other hand, certain morphemes are of a fusional character - see (7).

(7) He work-s in Prague.

In (7), the morpheme $-s$ expresses present tense, 3rd person singular number.

\subsection{German}

On the other hand, German, as another representative of Germanic languages, is an inflectional language. In terms of the index of synthesis, it can be positioned between English and Czech. As Finck (2010) or Roelcke (1997) point out, German combines the characteristics of a synthetic and analytic language. For example, verbal inflection is both analytic and synthetic, as shown below in (8) and (9) demonstrating the present active and passive, respectively.

(8) Sie durchsuch- en die Wohnung. they search 3.PL.PRES the flat

"They are searching the flat."

(9) Die Wobnung wird durchsucht. the flat PASS.AUX.3.SG.PRES search.PASS.PART

"The flat is being searched."

In terms of the index of fusion, German demonstrates features of fusion, as shown in (8) above, where -en carries tense, person and number features. On the other hand, agglutination is extremely productive with derivational morphology, see (10).

$\begin{array}{lll}\text { (10) } & \text { fass- } & \text { bar } \\ \text { not comprehend } & \text { able } \\ \text { "incomprehensible" } & \end{array}$ 


\subsection{Czech}

As Vachek $(1961,17)$ and Skalička (1951) observe, Czech is a highly synthetic language. Features such as case and number with nouns, or grading with adjectives are expressed by bound morphemes (11).

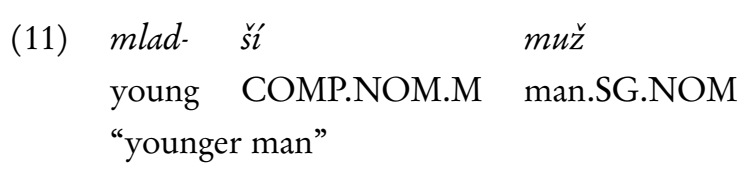

Analytic characteristics can be observed with prepositions (12), which are expressed as free morphemes, unlike in many other synthetic languages.

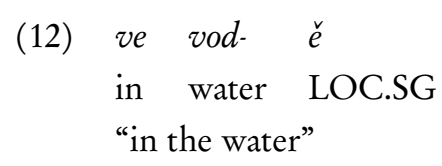

With respect to the index of fusion, Czech is a rather fusional language. One morpheme can realize several features, such as number and case, and these cannot be separated - see (13).
(13) kočk- ám
cat DAT.PL
"(to/for) cats"

Agglutination can be found in the word formation process (14a-c). In many cases, agglutination and inflection are combined.

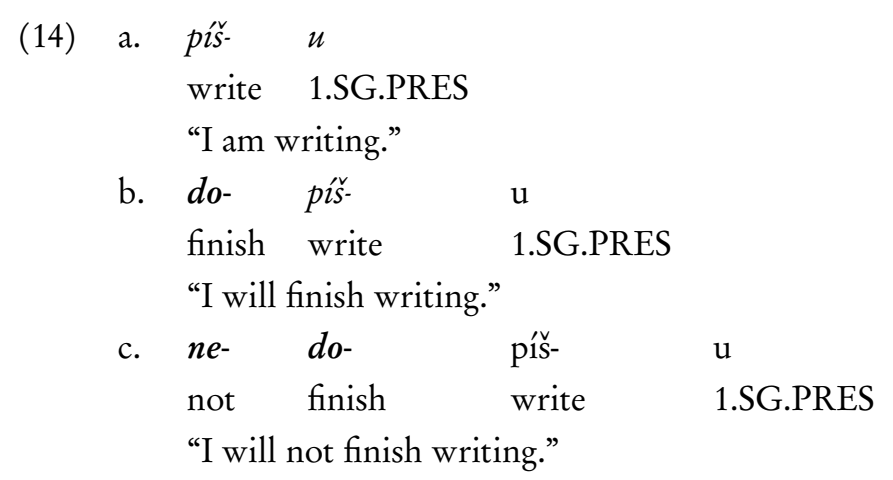

Referring to Figure 1, the three languages can be classified as follows, Figure 2.

$$
\begin{aligned}
& \text { analytic } \longleftarrow \text { English — German — Czech } \longrightarrow \text { synthetic } \\
& \text { agglutinative } \longleftarrow \text { English }- \text { German }- \text { Czech } \longrightarrow \text { fusional }
\end{aligned}
$$

Figure 2: Typology of English, German and Czech 
However, as mentioned above, such a comparison is rather approximate, since one language can combine all tendencies, i.e. in English, grading of adjectives can be analytic or synthetic, verbal morphology tends to be fusional, but derivation is often realized in an agglutinative manner.

\section{Terminological Issues}

\subsection{Tense and Aspect}

The terms tense and aspect are far from being trivial ones, and linguistic literature abounds in sources addressing these concepts from various perspectives. This paper will use Comrie's definition $(1985,9)$ that views tense as a grammaticalized expression of location in time. More precisely, a different set of morphological forms related to the same verb refers to present time (15a) or past time (15b) events.

(15) a. He works in Prague.

Another verbal subcategory in question is aspect. Unlike tense, aspect denotes how the action is viewed, rather than when. Hewson and Bubenik (1997, 12), quoting Comrie $(1976,5)$ define aspect as "internal temporal constituency of the one situation".

(16) a. She planted flowers yesterday.

b. She was planting flowers yesterday.

While both refer to past time, and are morphologically past tenses, (16a) refers to a completed event, whereas (16b) denotes the same process as ongoing. There are several linguistic means that can contribute to the aspectual meaning of a verb phrase in each language. One of them, Aktionsart, can can be encoded in a verb lexically: to study vs. to pass the test, by a prefix or sufix in Slavic languages, such as in psát (imp.) - napsat (perf.), as discussed in detail in Nübler (2017). This paper will, however, deal with grammatical aspect only, as illustrated in (16b) above.

\subsection{Formal vs. Functional Analysis of Verb forms}

Due to different grammatical traditions in the studies of English, German, and Czech languages, a crosslinguistic analysis of verbal forms used in the referred languages may not be straightforward. More precisely, various traditions may use divergent terminology for the same concepts, and such differences may render the analyses mutually incomparable. Generally, the verb forms can be either based on their formal structure, i.e. morphemes that they demonstrate, or functionally, referring to the time they denote. In most cases, the two approaches will lead to the same conclusions, but there are 
many cases, where applying formal or functional criteria lead to different results, as in (17).

(17) a. The seminar start-s tomorrow.

b. She ha-s read the book.

From the functional perspective, (17a) refers to the future time, whereas (17b) refers to the past time. Formally, however, (17a) is a present tense, demonstrating -s inflectional morpheme. Similarly (17b) is analysed as a present tense (in combination with a perfect aspect), again demonstrating the $-\mathrm{s}$ morpheme. This paper will analyze the tenses and aspects used in the three langauges solely from the formal perspective. In other words, we will analyze the inventory of morphemes available in English, German, and Czech, categorize them in terms of tense/aspect categories and compare them in the three languages. The paper will focus on verb forms referring to the present and the past, i.e. forms expressing future will not be discussed in detail.

\section{English Tense and Aspect Inventory}

The English language uses the combination of two grammatical tenses and two aspects. Tenses are expressed synthetically by $-s$ and $-e d$ morphemes for the present and past tense, respectively. ${ }^{3}$ The two tenses can be modified for analytic aspects - namely perfect and progressive. Perfect morphology includes have and -en morphology (past participle verb form). The progressive aspect is formed by the auxiliary be and -ing morpheme (present participle verb form), as shown in Table 1.

\begin{tabular}{lllll}
\hline & $\varnothing$ aspect & perfect aspect & progressive aspect & perfect aspect progressive aspect \\
\hline \hline present tense & work-s & ba-s work-ed & is work-ing & ba-s be-en work-ing \\
past tense & work-ed & ba-d work-ed & was work-ing & ba-d be-en work-ing \\
\hline
\end{tabular}

Table 1: English tense and aspect inventory

Notice that all verb forms in Table 1 are fully constitutional. In other words, each verb form can be decomposed into a verbal root and respective tense/aspect morphology.

3 Although many grammar manuals regard future as another tense, this paper will not consider English will to be a tense. The authors regard will as a modal, as argued, for example, in Machová $(2015,50)$, which inherently refers to the future as any other modal, and thus is replaceable by any member from the category - see (i).

(i) The project will/must have been finished by Monday. 
In terms of semantics of the verb forms, their temporal (present, past) and aspectual meaning (perfect, progressive) is based on their tense and aspect elements. As a result, the present perfect denotes states and actions that are completed (aspect) with respect to the present time (tense), and the past perfect denotes actions that are completed (aspect) with respect to the past time (tense). Thus, the use of the present perfect for finished past events yields ungrammatical sentences - see (18).

(18) *I have seen him yesterday.

As has been illustrated, English uses two tenses, which are synthetic, and two aspects, which are analytic. Their combinations form eight verb forms in total that can be used for expressing present and past states and events.

\section{German Tense and Aspect Inventory}

Traditionally, the German tense inventory is presented as follows: Präsens (present), Präteritum (preterite), Perfekt (perfect), Plusquamperfekt (past perfect), and Futur I and Futur II (future I and II), as described, for example, in Helbig and Buscha (2001, 122). Due to their time references, there is a tendency to group them as follows:

- present - Präsens

- past - Perfekt, Präteritum, Plusquamperfekt

- future - Futur I, Futur II ${ }^{4}$

Such analysis is based on a functional approach. This paper, however, focuses on a formal analysis of the verb forms and, therefore, we will analyse them based on their subcategories - tense and aspect. Under this approach, German has two tenses, namely Präsens/present and Präteritum/preterite. These are expressed, similarly to English, by bound morphology (suffix or Ablaut with strong verbs), see (19a) and (19b), showing present and preterite morphology.

$$
\begin{aligned}
& \text { a. Ich arbeit } \boldsymbol{e} \text { jede } n \text { Tag. } \\
& \text { I work 1.SG.PRES every SG.M.ACC day } \\
& \text { "I work every day." } \\
& \text { b. Ich arbeit } \text { et } \text { - } e \text { jede- } n \text { Tag. } \\
& \text { I work PAST 1.SG.PRES every SG.M.ACC day } \\
& \text { "I worked every day." }
\end{aligned}
$$

\footnotetext{
4 The authors of this paper challenge the idea of Futur I and Futur II as tenses, for the same reasons as in English. More precisely, werden is a modal verb, as argued in Machová $(2015,144)$, and future reference is an inherent property of modals. Also, Duden $(2009,508)$ stresses the modal meaning of future, stating that it stands in between the categories of tense and mood.
} 
Similarly to English, these two tenses can be modified by a perfect aspect, consisting of auxiliary haben "have" or sein "be" in combination with past participle, thus verb + -en. As a result, the perfect aspect can be combined with Präsens into Perfekt (present perfect), and Präteritum into Plusquamperfekt (past perfect) - see (20a) and (20b) respectively. ${ }^{5}$
a. Ich hab. $e$
das ge-mach-t.
I have 1.SG.PRES it do.PAST.PART
"I have done that."
b. Ich hab- $t$ - $e$ das ge-mach-t.
I have PAST 1.SG.PRES it do.PAST.PART
"I had done that."

When such a viewpoint is adopted, the German temporal system demonstrates a wellstructured layout, not very different from the English one, as shown in Table 2.

\begin{tabular}{lll}
\hline & $\varnothing$ aspect & perfect aspect \\
\hline \hline Präsens/present tense & mach-e & ha-t ge-mach-t \\
Präteritum/past tense & mach-t-e & hat-t-e ge-mach-t \\
\hline
\end{tabular}

Table 2: German tense and aspect inventory

Despite the fact that the German system overlaps with the English one to a great extent, the verbal complexes do not have identical semantics, and they are not used in exactly the same contexts. To mention one example, German Perfekt is used in a different way than English present perfect. In particular, German Perfekt can be interchanged with simple Präteritum in situations when the aspect of anteriority is not stressed - compare (21a) for German and (21b) for English.
(21) a. Wir blieben letzten Sommer bier. $=$ Wir sind letzten Sommer hier geblieben.
b. We stayed here last summer. $\quad \neq *$ We have stayed here last summer.

Whereas in English, the difference between past and present perfect is grammatical, the difference in German is rather a stylistic or regional one.

\footnotetext{
5 This analysis is also implied in Engel (1996, 494ff.), who states that "das Perfekt is primär eine Präsensform, ein präsentischer Komplex," [transl:: Perfekt is primarily a present form, a present complex]. Präterium is defined as „einzige reine Vergangenheitstempus,” [transl.: the only pure past form]. In the same vein, Duden (2009) uses even more transparent terminology, namely Präsensperfekt and Präteritumperfekt.
} 


\section{Czech Tense and Aspect Inventory}

Traditionally, Czech is claimed to have three tenses, namely synthetic present (22a), analytic preterite (22b), and analytic future $(22 \mathrm{c})^{6}$, as for example in Komárek and Kořenský (1986, 163ff.) or Štícha et. al (2017) ${ }^{?}$
a. (Já) var̀- ím.
I cook 1.SG.PRES
"I cook/I am cooking."
b. Já js- em textitvaři- textitl- textita.
I be.AUX 1.SG.PRES cook PAST FEM
"I cooked/I was cooking."
c. (Já) bud- u textitvařit.
I be.AUX.FUT 1.SG.PRES cook
"I will cook/I will be cooking."

Despite the fact that Czech is a synthetic language, preterite is expressed analytically more precisely by auxiliary být "to be" $+-l$ participle, as shown in (22b) ${ }^{8}$ However, $3^{\text {rd }}$ person singular and plural are synthetic, i.e. the auxiliary být "to be " is ungrammatical in this case - see the singular paradigm for the verb "cook" in (23).

(23)

$\begin{array}{llll} & \text { PRON.PERS } & \text { AUX } & \text { cook.PART } \\ \text { a. } & J a ́ & j s e m & \text { vaŕil. } \\ \text { b. } & T y & j s i & \text { vaŕil. } \\ \text { c. } & \text { On } & \varnothing / * j e & \text { vaŕil. }\end{array}$

Moreover, there is a strong tendency for cliticization of the auxiliary into $-s(23)$, or a complete erosion of the auxiliary in spoken language (similarly to Russian or Polish); compare (24) with (22b).

6 The authors of this paper challenge the idea of future being a tense for the same reasons as in English and German.

7 Komárek and Kořenský (1986, 163ff.) as well as Štícha et. al (2017) point to the existence of Czech antepreterite (pluperfect), as exemplified below in (i). This verb form is, however, archaic and ungrammatical in present-day Czech.

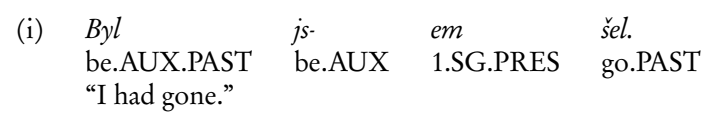

8 Despite the fact that the structure auxiliary + participle resembles the structure of the grammatical aspect in English or German, this Czech verb form functions in present-day Czech as a pure tense category, e.g. it is non-existent in non-finite contexts. Furthermore, as Karlík and Migdalski (2017) point out, morphosyntactic properties of lexical být "to be" and preterital být "to be" are significantly different. 
(23) a. Ty js- $i \quad$ vaŕil.

You be.AUX 2.SG.PRES cook.PART

"You cooked."

b. Ty-s varill./Ty vařil-s.

(24) Já(jsem) vařil.

"I was cooking."

Besides the category of tense, Czech also demonstrates a trace of a grammatical aspect, frequently labelled as Slavic perfect. Its structure consists of the auxiliary mít "to have" and present participles, as exemplified in (25).

\begin{tabular}{|c|c|c|c|c|c|}
\hline$M-$ & $a ́ m$ & $u-$ & vaŕ & $e n$ - & $o$. \\
\hline have & 1.SG.PRES & PERF & cook & PRES.PART & NEUTR. \\
\hline
\end{tabular}

In (25), the perfect aspect is combined with the present tense -ám morpheme. But as expected, the aspect can be used also in combination with a past tense (26), or even with a future tense.

\begin{tabular}{|c|c|c|c|c|c|c|c|}
\hline$M$ & él & $j s-$ & $\mathrm{em}$ & $u-$ & $v a \grave{r}$ & en- & $o$. \\
\hline have & PAST.PART & be.AUX & 1.SG.PRES & PERF & cook & PRES.PART & NEUTR. \\
\hline
\end{tabular}

Tense morphology is expressed in (26) by the auxiliary být "to be " + -1 participle of mít "to have". On the other hand, aspect morphology is expressed by mít "to be" and present participle uvařeno. As Karlík and Migdalski (2017) point out, semantically, the form mít + participle carries the meaning of anteriority, similarly to English perfect aspect; see the example of the parallel sentences in (27), where (27a) showns Czech preterite, whereas (27b) demonstrates past perfect.

(27) a. Když jsem prišsel, Petr uvařil oběd.

"When I came, Peter cooked lunch."

b. Když jsem prǐšel, Petr měl uvařen oběd. ${ }^{9}$

"When I came, Peter had cooked lunch."

Despite the fact that the Czech perfect seems to be a counterpart of the English perfect aspect, it is generally not listed as a grammatical category. Karlík and Migdalski (2017) point out that Slavic perfect makes the verb action become static, and therefore, they find it problematic to categorize it as a true perfect. Slavic perfect is also incompati-

9 This example also has an alternative interpretation, namely "When I came, lunch had been cooked for/by Peter." 
ble with imperfective verbs due to semantic reasons (this is similar to future). Clancy (2010, 185ff.), despite labelling this construction as a new perfect, states that the verbal complex stands in between a true perfect and a resultative construction (28a-b), and as a grammatical construction, it is still subject to grammaticalization.

(28) a. I have done my homework. perfect aspect

b. I bave my bomework done. resultative construction

The following table summarizes the verbal forms of Czech.

\begin{tabular}{lll}
\hline & $\varnothing$ aspect & ? perfect aspect \\
\hline \hline present tense & vař́lm & $m$-ám u-vaŕ-eno \\
preterite/past tense & vaŕ-il js-em & $m$-él js-em u-vaŕ-eno \\
\hline
\end{tabular}

Table 3: Czech tense and aspect inventory

Slavic perfect is marked with a question mark. Taking this into consideration, the Czech language possesses the poorest tense and (grammatical) aspect inventory of the three languages.

\section{Conclusion}

The aim of this paper was to investigate verbal forms used for denoting present and past states and actions in English, German, and Czech. In this regard, all languages have the same inventory of tenses - namely present and preterite. In English and German, these are expressed synthetically, whereas in Czech, which is regarded the most synthetic of all three, preterite is expressed analytically. As for the aspect, all three languages demonstrate the morphology of a perfect aspect. As concerns the progressive aspect, English is the only language, in which the progressive aspect is a part of the verbal category, i.e. is fully grammaticalized - see the following table. 


\begin{tabular}{lccc}
\hline & English & German & Czech \\
\hline \hline present tense + Ø aspect & $\checkmark$ & $\checkmark$ & $\checkmark$ \\
present tense + perfect aspect & $\checkmark$ & $\checkmark$ & ? \\
present tense + progressive aspect & $\checkmark$ & & \\
present tense + perfect aspect + progressive aspect & $\checkmark$ & & \\
past tense + Ø aspect & $\checkmark$ & $\checkmark$ & $\checkmark$ \\
past tense + perfect aspect & $\checkmark$ & $\checkmark$ & $?$ \\
past tense + progressive aspect & $\checkmark$ & & \\
past tense + perfect aspect + progressive aspect & $\checkmark$ & & \\
\hline
\end{tabular}

Table 4: English, German and Czech compared

Despite the fact that all languages use the perfect aspect, its function differs significantly in English, German, and Czech. In English, the perfect aspect has a grammatical function, which means that it obligatorily expresses anteriority and completeness. Despite the fact that the German perfect aspect can express the same meanings, its distribution is related rather to the stylistic properties of a text. In Czech, on the other hand, perfect morphology does exist - it is however, not fully grammaticalized.

\section{References}

Clancy, Steven. 2010. The Chain of Being and Having in Slavic. Amsterdam: John Benjamins.

Comrie, Bernard. 1976. Aspect. Cambridge: Cambridge University.

Comrie, Bernard. 1985. Tense. Cambridge: Cambridge University.

Comrie, Bernard. 1989. Language Universals and Linguistic Typology. Second Edition. Oxford: Blackwell.

Duden - Die Grammatik: Unentbehrlich für richtiges Deutsch: Band 4. 2009. Mannheim: Dudenverlag.

Engel, Ulrich. 1996. Deutsche Grammatik. Heidelberg: Julius Groos Verlag.

Finck, Franz Nikolaus. 1910. Die Haupttypen des Sprachbaus. Leipzig: B.G. Teubner.

Helbig, Gerhard, and Joachim Buscha. 2001. Deutsche Grammatik. Berlin: Langescheidt.

Hewson, John, and Vit Bubenik. Tense and Aspect in Indo-European Languages. Amsterdam: John Benjamins.

Karlík, Petr, and Krzysztof Migdalski. (2017). "Préteritum.” In Nový encyklopedický slovník češtiny online. Accessed September 26, 2017. https://www.czechency.org/slovnik/PRÉTERITUM

Komárek, Miroslav, and Jan Kořenský. 1986. Mluvnice češtiny 2. Tvarosloví. Prague: Academia.

Machová, Dagmar. 2015. "Polyfunctionality and the Ongoing History of English Modals.” Ph.D. diss., Palacký University.

Nübler, Norbert. 2017. “Způsob slovesného děje.” In Nový encyklopedický slovník češtiny online. Accessed September 26, 2017. https://www.czechency.org/slovnik/ZPŮSOB SLOVESNÉHO DĚJE 
Roelcke, Thorsten. 1997. Sprachtypologie des Deutschen. Berlin / New York: De Gruyter.

Sapir, Edward. 1921. Language: An Introduction to the Study of Speech. New York: Harcourt, Brace and Company. Accessed September 26, 2017. http://www.bartleby.com/186/

Skalička, Vladimír. 1951. Typ češtiny. Prague: Slovanské nakladatelství.

Skalička, Vladimír. 1966. "Ein "typologisches Konstrukt”." Travaux linguistiques de Prague 2: 157-164.

Štícha, František, Milada Hirschová, and Susan Kresin. 2017. "Slovesný čas." In Nový encyklopedickýslovnik češtiny online. Accessed September 26, 2017. http://www.czechency.org/slovnik/ SLOVESNÝ ČAS

Vachek, Josef. 1961. "Some less familiar aspects of the analytical trend of English." Brno Studies in English 3: 9-78.

\section{Appendix: Glossing}

\begin{tabular}{|c|c|}
\hline Abbreviation & Explanation \\
\hline 1 & First person \\
\hline 1.SG & First-person singular \\
\hline 3.PL & Third-person plural \\
\hline $\mathrm{ACC}$ & Accusative \\
\hline AUX & Auxiliary \\
\hline COMP & Comparative \\
\hline DAT & Dative \\
\hline FEM & Feminine \\
\hline FUT & Future \\
\hline GEN & Genitive \\
\hline LOC & Locative \\
\hline $\mathrm{M}$ & Masculine \\
\hline NEUTR & Neuter \\
\hline NOM & Nominative \\
\hline PART & Participle \\
\hline PASS & Passive \\
\hline PAST & Past \\
\hline PERF & Perfect \\
\hline PERS & Personal \\
\hline PL & Plural \\
\hline PRES & Present \\
\hline PRON & Pronoun \\
\hline SG & Singular \\
\hline
\end{tabular}

